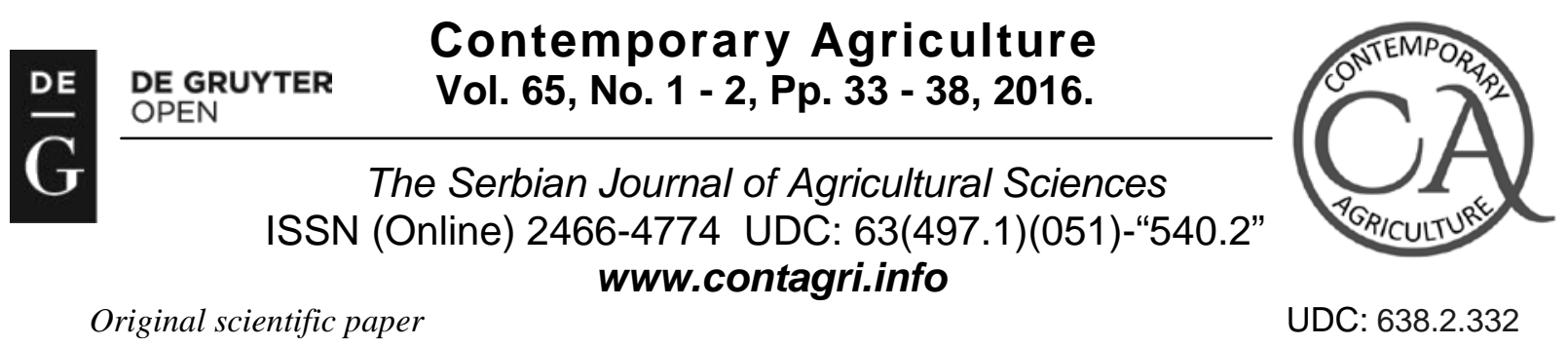

DOI: 10.1515/contagri-2016-0006

\title{
MICROBIAL ACTIVITY IN FOREST SOIL UNDER BEECH, SPRUCE, DOUGLAS FIR AND FIR
}

\author{
Timea HAJNAL-JAFARI ${ }^{11}$, Simonida ĐURIĆ ${ }^{1}$, Dragana STAMENOV ${ }^{1}$, \\ Verica VASIĆ ${ }^{2}$, Davorka HACKENBERGER ${ }^{3}$
}

\begin{abstract}
Summary: The aim of this research was to investigate the microbial activity in forest soil from different sites under deciduous and coniferous trees in Serbia. One site on Stara planina was under beech trees (Fagus sp.) while another under mixture of spruce (Picea sp.) and Douglas fir (Pseudotsuga sp.). The site on Kopaonik was under mixture of beech (Fagus sp.) and spruce (Picea sp.) trees. The site on Tara was dominantly under fir (Abies sp.), beech (Fagus sp.) and spruce (Picea sp.). The total number of bacteria, the number of actinobacteria, fungi and microorganisms involved in $N$ and $C$ cycles were determined using standard method of agar plates. The activities of dehydrogenase and B-glucosidase enzymes were measured by spectrophotometric methods. The microbial activity was affected by tree species and sampling time. The highest dehydrogenase activity, total number of bacteria, number of actinobacteria, aminoheterotrophs, amylolytic and cellulolytic microorganisms were determined in soil under beech trees. The highest total number of fungi and number of pectinolytic microorganisms were determined in soil under spruce and Douglas fir trees. The correlation analyses proved the existence of statistically significant interdependency among investigated parameters.
\end{abstract}

Key words: microorganisms, forest soil, dehydrogenase, ß-glucosidase activity.

\section{INTRODUCTION}

Soil chemical and microbiological characteristics are directly as well as indirectly affected by the dominant tree species (Priha et al., 2001). Forest soils are known for its constant and high inputs of plant materials, therefore those soils are rich in organic carbon (C) compounds as well as in microbial biomass. Plant litter C together with the C from plant roots represents the dominant sources of $\mathrm{C}$ in temperate forest soils. Microbial decomposition of soil organic matter (SOM) represents a key driver of the forest's $\mathrm{C}$ and $\mathrm{N}$ cycle. In temperate forest ecosystems a seasonal pattern of microbial processes is related to a seasonal variation in availability of different substrates, as well as variation in soil temperature and moisture (Kaiser et al., 2011). Many studies have focused on the quantification of microbial biomass and enzyme activities in forest soils (Šnajdr et al., 2008). However, studies of forest soils microbial activities in Serbia are in its infancy, since quantitative and qualitative determination of microbial populations and enzymatic activity starts in the last decade.

The aim of this work was to quantify the microbiological activity in the soil under beech (Fagus sp.), spruce (Picea sp.), Douglas-fir (Pseudotsuga sp.) and fir ( Abies sp.).

\footnotetext{
${ }^{1}$ Timea Hajnal Jafari, PhD, Assistant Professor, Simonida Đurić, PhD, Assistant Professor, Dragana Stamenov, PhD, Research Associate, University of Novi Sad, Faculty of Agriculture, Department for Field and Vegetable crops, Sq. D. Obradović 8, 21000 Novi Sad, Serbia.

${ }^{2}$ Verica Vasić, PhD, Senior Research Associate, Institute of Lowland Forestry and Enviroment, Anton Cehov 13, 21000 Novi Sad, Serbia.

${ }^{3}$ Davorka Hackenberger, PhD, Faculty of Education, J. J. Strossmayer University in Osijek, Department of Biology, Cara Hadrijana, Osijek, Croatia.

• Corresponding author: e-mail: mikrobiologija@polj.uns.ac.rs. Tel.: +381214853427
} 


\section{MATERIAL AND METHODS}

One site on Stara planina (SP1) was under beech trees (Fagus sp.) while another (SP2) under mixture of spruce (Picea sp.) and Douglas fir (Pseudotsuga sp.). The site on Kopaonik (K) was under mixture of beech (Fagus sp.) and spruce (Picea sp.) trees. The site on Tara (T) was dominantly under fir (Abies sp.), beech (Fagus sp.) and spruce (Picea sp.). The soil chemical and physical characteristics are presented in Table 1. At all sites, the composition of the plant communities is considered to be natural, which means that it has not been changed by human interference.

Table 1. Soil chemical and physical characteristics

\begin{tabular}{|l|c|c|c|c|c|c|c|c|c|c|}
\hline Site & $\begin{array}{c}\text { Depth } \\
(\mathrm{cm})\end{array}$ & $\begin{array}{c}\mathrm{CaCO}_{3} \\
(\%)\end{array}$ & $\begin{array}{c}\mathrm{Humus} \\
(\%)\end{array}$ & $\begin{array}{c}\mathrm{pH} \text { in } \\
\mathrm{H}_{2} \mathrm{O}\end{array}$ & $\begin{array}{c}\text { Nitrogen } \\
(\%)\end{array}$ & $\begin{array}{c}\mathrm{P}_{2} \mathrm{O}_{5} \\
(\mathrm{mg} / \mathrm{kg})\end{array}$ & $\begin{array}{c}\mathrm{K}_{2} \mathrm{O} \\
(\mathrm{mg} / \mathrm{kg})\end{array}$ & $\begin{array}{c}\text { Total } \\
\text { sand (\%) }\end{array}$ & $\begin{array}{c}\text { Total } \\
\text { clay } \\
(\%)\end{array}$ & Texture \\
\hline $\mathrm{SP} 1$ & $0-30$ & 0,42 & 4,00 & 6,41 & 0,25 & 9,5 & 7,8 & 39,80 & 60,20 & Clay loam \\
\hline $\mathrm{SP} 2$ & $0-30$ & 0,00 & 3,60 & 6,15 & 0,10 & 8,0 & 6,4 & 66,00 & 34,00 & Sandy clay \\
\hline $\mathrm{K}$ & $0-30$ & 0,00 & 3,00 & 4,83 & 0,15 & 6,5 & 5,4 & 77,00 & 23,00 & Sandy clay \\
\hline $\mathrm{T}$ & $0-30$ & 2,10 & 10,17 & 4,76 & 0,39 & 6,9 & 5,5 & 72,00 & 28,00 & Sandy clay \\
\hline
\end{tabular}

Soil samples were taken from the depth of 0-30 cm, after the removal of plant litter performed in June and August in 2012. At each site, four replicate bulk samples were taken, consisting of 10 randomly collected subsamples. Soil samples were places in sterile polyurethane bags and kept on temperature of $4^{0} \mathrm{C}$. After transportation to the laboratory, the samples were sieved through a $2 \mathrm{~mm}$ sieve and stored until used.

Microbiological measurements included the determination of total number of bacteria, actinobacteria, fungi, aminoheterotrophs, amylolytic, cellulolytic and pectinolytic microorganisms. Activity of enzymes dehydrogenase and $\beta$-glucosidase were also measured. The number of microorganisms were determined by standard agar plate method (Trolldenier, 1996) preparing a ten-fold dilution series, and applying the appropriate dilutions on nutrient plates. After incubation, plates were inspected. The number of microorganisms was calculated to one gram absolutely dry soil and presented as CFU/g soil. Dehydrogenase activity of soil was determined spectrophotometrically (Lenhard, 1956; Thalmann, 1968). The activity of enzyme $\beta$-glucosidase was measured by method of Hayano, (1973).

Statistical data analyses were performed using STATISTICA 12 software (Hamburg, Germany). Data were treated with two-way analysis of variance. Means were compared using Fisher test $(p<0.05)$. Correlation analysis was performed to determine whether there were any linear relationships among treatments.

\section{RESULTS}

The number of the investigated groups of microorganisms and enzymatic activity of forest soils were influenced by tree species and soil sampling time. The results of this study are shown in Table 2.

Table 2. Microbiological activity in forest soil

\begin{tabular}{|c|c|c|c|c|}
\hline & (Fagus sp.) & $\begin{array}{c}\text { (Picea sp. } \\
+ \\
\text { Pseudotsuga sp.) }\end{array}$ & $\begin{array}{c}\text { (Fagus sp. } \\
+ \\
\text { Picea sp.) }\end{array}$ & $\begin{array}{c}\text { (Abies sp.+ } \\
\text { Fagus sp. }+ \\
\text { Picea sp.) }\end{array}$ \\
\hline \multicolumn{5}{|c|}{ TNB ( $10^{5}$ CFU/g soil) } \\
\hline I sampling & $92,47^{\mathrm{a}}$ & $25,50^{\mathrm{d}}$ & $20,94^{\mathrm{d}}$ & $16,70^{\mathrm{d}}$ \\
\hline II sampling & $71,88^{\text {ab }}$ & $39,25^{\text {cd }}$ & $61,57^{\mathrm{bc}}$ & $42,72^{\mathrm{abc}}$ \\
\hline \multicolumn{5}{|c|}{ ACT ( $10^{4}$ CFU /g soil) } \\
\hline I sampling & $14,30^{\mathrm{a}}$ & $1,58^{\mathrm{b}}$ & $0,94^{\mathrm{b}}$ & $0^{\mathrm{b}}$ \\
\hline II sampling & $0,56^{\mathrm{b}}$ & $0,63^{\mathrm{b}}$ & $0,42^{\mathrm{b}}$ & $0,17^{\mathrm{b}}$ \\
\hline \multicolumn{5}{|c|}{ FNG ( $10^{3}$ CFU /g soil) } \\
\hline I sampling & $14,95^{b}$ & $31,75^{\mathrm{a}}$ & $0,91^{\mathrm{e}}$ & $6,63^{\mathrm{cd}}$ \\
\hline II sampling & $8,76^{\mathrm{c}}$ & $19,56^{\mathrm{b}}$ & $1,67^{\text {de }}$ & $0,78^{\mathrm{e}}$ \\
\hline
\end{tabular}




\begin{tabular}{|c|c|c|c|c|}
\hline \multicolumn{5}{|c|}{ AMH ( $10^{5}$ CFU /g soil) } \\
\hline I sampling & $30,40^{b}$ & $10,32^{\mathrm{C}}$ & $5,52^{\mathrm{C}}$ & $4,82^{\mathrm{C}}$ \\
\hline II sampling & $74,53^{\mathrm{a}}$ & $9,60^{c}$ & $3,11^{\mathrm{c}}$ & $1,40^{\mathrm{C}}$ \\
\hline \multicolumn{5}{|c|}{ AML( $10^{5}$ CFU /g soil) } \\
\hline I sampling & $20,76^{\mathrm{a}}$ & $8,74^{b}$ & $1,02^{\mathrm{cd}}$ & $3,65^{\text {bcd }}$ \\
\hline II sampling & $6,29^{\mathrm{bc}}$ & $1,88^{\mathrm{cd}}$ & $0,75^{\mathrm{cd}}$ & $0,15^{\mathrm{d}}$ \\
\hline \multicolumn{5}{|c|}{ CEL( $10^{4}$ CFU /g soil) } \\
\hline I sampling & $29,91^{\mathrm{a}}$ & $20,63^{\mathrm{ab}}$ & $33,14^{\mathrm{a}}$ & $1,82^{\mathrm{C}}$ \\
\hline II sampling & $9,19^{b}$ & $10,17^{\mathrm{bc}}$ & $2,51^{\mathrm{C}}$ & $2,34^{\mathrm{c}}$ \\
\hline \multicolumn{5}{|c|}{$\operatorname{PEC}\left(10^{2} \mathrm{CFU} / \mathrm{g}\right.$ soil $)$} \\
\hline I sampling & $168,08^{\mathrm{a}}$ & $165,19^{\mathrm{a}}$ & $11,07^{b}$ & $18,07^{b}$ \\
\hline II sampling & $11,39^{b}$ & $49,38^{b}$ & $1,67^{\mathrm{b}}$ & $3,90^{b}$ \\
\hline \multicolumn{5}{|c|}{ DHA ( $\mu$ g TPF/10g soil) } \\
\hline I sampling & $676,2^{b}$ & $196,2^{c}$ & $240,0^{\mathrm{C}}$ & $92,4^{\mathrm{C}}$ \\
\hline II sampling & $1115,8^{\mathrm{a}}$ & $149,5^{c}$ & $172,4^{\mathrm{C}}$ & $30,5^{c}$ \\
\hline \multicolumn{5}{|c|}{ GLU ( $\mu$ mol p-NP/5g soil) } \\
\hline I sampling & $48,07^{\mathrm{a}}$ & $34,33^{b}$ & $49,10^{\mathrm{a}}$ & $49,27^{\mathrm{a}}$ \\
\hline II sampling & $22,80^{b}$ & $22,33^{b}$ & $26,37^{b}$ & $30,07^{b}$ \\
\hline
\end{tabular}

Note: same letter in superscript indicates no statistically significant difference between mean values on the basis of LSD test $(\mathrm{p}<0.05)$; TNB-total number of bacteria, ACT-actinobacteria, FNG-fungi, AMH-aminoheterotrophs, AMLamylolytic mo, CEL-celullolytic mo, PEC-pectinolytic mo, DHA-dehydrogenases, GLU- $\beta$-glucosidases

Microbial abundance was more influenced by tree species. The highest total number of bacteria, actinobacteria, bacteria from $\mathrm{C}$ and $\mathrm{N}$ cycle were determined in soil under beech. The dehydrogenase activity was also much higher under beech stands. Sites under dominantly coniferous trees were characterized by decreased microbial number in soil but increased enzymatic activity. The dehydrogenase activity in soil under fir, beech and spruce was more than ten times less in comparison with its activity on site under beech trees. However, $\beta$-glucosidase activity was higher under spruce and fir, beech, spruce, respectively. Some general observations were made concerning the relations between investigated parameters of soil microbial activities. Correlation analysis proved the existence of statistically significant interdependency among treatments (Table 3).

Table 3. Spearman Rank Order Correlations

\begin{tabular}{|c|c|c|c|c|c|c|c|c|}
\hline & TNB & ACT & FNG & AMH & AML & CEL & PEC & DHA \\
\hline ACT & $0,433^{*}$ & & & & & & & \\
\hline FNG & $0,416^{*}$ & $0,710^{*}$ & & & & & & \\
\hline AMH & $0,482^{*}$ & $0,567^{*}$ & $0,444^{*}$ & & & & & \\
\hline AML & 0,078 & $0,615^{*}$ & $0,686^{*}$ & 0,401 & & & & \\
\hline CEL & 0,085 & $0,560^{*}$ & $0,480^{*}$ & $0,475^{*}$ & 0,361 & & & \\
\hline PEC & 0,086 & $0,594^{*}$ & 0,542 & $0,541^{*}$ & $0,858^{*}$ & $0,542^{*}$ & & \\
\hline DHA & 0,396 & $0,825^{*}$ & 0,560 & $0,493^{*}$ & 0,307 & $0,639^{*}$ & 0,336 & \\
\hline GLU & $-0,148$ & $-0,006$ & 0,179 & 0,031 & $-0,089$ & $0,455^{*}$ & 0,161 & 0,072 \\
\hline
\end{tabular}

Note: ${ }^{*}$ in superscript: correlations are statistically significant at $\mathrm{p}<, 05000$;

TNB-total number of bacteria, ACT-actinobacteria, FNG-fungi, AMH-aminoheterotrophs, AML-amylolytic mo, CELcellulolytic mo, PEC-pectinolytic mo, DHA-dehydrogenase activity, GLU- $\beta$ glucosidase activity 


\section{DISCUSSION}

Nutrient cycles and ecosystem functioning is heavily influenced by seasonal changes of soil microbial biomass (Lipson and Schmidt, 2004). This research showed that the number of most investigated groups of microorganisms was highest in soil under beech stands (SP1). Soil on that site has good chemical and physical characteristics, as mentioned. This suggests the existance of favorable conditions in soil for microbial growth. The high $\mathrm{pH}$ of the beech plots would favor the growth of bacteria (Killham, 1994), and may also account for the lower fungal biomass associated with this tree species. This is consistent with the findings of Frostegard and Baath (1996). They found higher fungal: bacterial ratios in more acid coniferous forest soils than in beech forest soils of higher $\mathrm{pH}$, based on PLFA profiles. The high bacterial:fungal ratio in beech forest soil might also be related to their higher moisture content. Gram-negative bacteria, including pseudomonads are particularly sensitive to water stress (Killham, 1994). Gram-positive bacteria, in particular actinomycetes, are amongst the most water stress tolerant of all soil organisms.

The relative abundance of bacteria increased with pH (Högberg et al., 2007). Soils under beech-spruce (K) and fir-beech-spruce (T) were less favorable for microorganisms. Many systematic and physiological groups of microorganisms, as well as dehydrogenase activity were decreased in comparison with soils under beech (SP1) and spruce-Douglas fir (SP2). This can be explained by lower soil $\mathrm{pH}$, moisture content, nutrient availability and specificity of forest litter. As mentioned, coniferous trees are dominating on these two sites. Many researchers stated that Norway spruce is a tree species which gradually change soil fertility in an unfavorable direction by lowering the soil $\mathrm{pH}$, decomposition rates and concentration of exchangeable nutrients (Priha and Smolander, 1997; Menyailo et al., 2002). However, $\beta$-glucosidase activity was higher in acidic soils. This finding is in accordance with the results of Das et al. (2011). The authors found that the cellulase activity decreases with the increase in $\mathrm{pH}$ values. The highest mean value was found at $\mathrm{pH} 5.0$ and the lowest at $\mathrm{pH}$ 8.0. In the temperate zone, soil moisture content does not represent a limitation of enzymatic activity because it does not drop to low values for long times (Baldrian et al., 2013). Differences between tree species may also be due to differences in ground vegetation, since herbs and grasses were more abundant in the deciduous stand than in the coniferous stands (Nieminen and Smolander, 2006). On the other hand, moss litter has a lower $\mathrm{pH}$ and decomposes more slowly than the dead parts of most herbs and grasses (Mikola, 1954). Furthermore, coniferous trees produce numerous secondary metabolites, e.g. phenols and tannins (Manninen et al., 2002). Phenols and especially tannins affect the mineralization of organic $\mathrm{C}$ and $\mathrm{N}$ compounds, they have a toxic effect on microorganisms and inhibit soil enzymatic activity (Kanerva et al., 2006).

In this research the counts of actinobacteria, fungi, aminoheterotrophs and cellulolytic microorganisms positively correlated with dehydrogenase activity while the cellulolytic enzyme activity correlated only with the number of cellulolytic microorganisms. It means that the microbial community, largely composed of bacteria, is metabolically active. Fungi are also known to be responsible for the production of many enzymes in soils (Theuerl and Buscot, 2010), although they presence in the forest soil does not always result in elevated enzyme activity. Often saprotrophic fungi in the forest soil are metabolically inactive.

\section{CONCLUSION}

In conclusion, result of this study gave us an insight about the current picture regarding microbial activity in forest soils on several locations. This research was based on analyses of culturable bacteria and fungi, hence the findings were created according to these parameters. In average, bacteria were more abundant in soil and the most favorable conditions for microbial growth were in soil under beech trees. Of course, one year data are not sufficient or reliable enough to create a trend or make a conclusion because of huge heterogenicity and variability of numerous factors (soil conditions, tree species, climatic factors, sampling time and place among the most important). The implementation of few other techniques (e.g. methods of molecular determination, analyses of microbial C, N and P biomass, biochemical tests) are essential to gain a better insight in forest ecosystem functioning.

\section{REFERENCES}

BALDRIAN, P., ŠNAJDR, J., MERHAUTOVA, V., DOBIAŠOVA, P., CAJTHAMI, T., VALAŠKOVA, V.: Responses of the extracellular enzyme activities in hardwood forest to soil temperature and seasonality and the potential effects of climate change. Soil Biology and Biochemistry, 56: 60-68, 2013.

DAS B., ASHIS CH., GHOSH S., CHAKRABARTI K.: Studies on the effect of pH and carbon sources on enzyme activities of some pectinolytic bacteria isolated from jute retting water. Turkish Journal of Biology, 35: 671-678, 2011

FROSTEGARD A., BAATH E.: The use of phospholipid fatty acid analysis to estimate bacterial and fungal biomass in soil. Biology and Fertility of Soils, 22: 59-65, 1996. 
HAYANO K.: A method for the determination of b-glukosidase activity in soil. Soil Science and Plant Nutrition, 19: 103-108, 1973.

HÖGBERG M.N., HÖGBERG P., MYROLD D.D.: Is microbial community composition in boreal forest soils determined by pH, C-to-N ratio, the trees, or all three? Oecologia, 150: 590-601, 2007.

KAISER C., FUCHSLUENGER L., KORANDA M., GORFER M., STANGE C., KITZLER B., RASCHE F., STRAUSS J., SESSITSCH A., ZECHMEISTER-BOLTENSTERN S., RICHTER A.: Plants control the seasonal dynamics of microbial N cycling in a beech forest soil by belowground C allocation. Ecology, 92: 1036-1051, 2011.

KANERVA S., KITUNEN V., KIIKKILÄ O., LOPONEN J., SMOLANDER A.: Response of soil C and N transformations to tannin fractions originating from Scots pine and Norway spruce needles. Soil Biology and Biochemistry, 38: 1364-1374, 2006.

KILLHAM K.: Soil ecology. Cambridge: Cambridge University Press. p. 242, 1994.

LENHARD G.: Die dehydrogenase aktivitat das Bodeusald Mass fur die Mikroorganizmentatigk eit im Boden. Z. Pflansenern. Dung Bodenkude, 73: 1-11, 1956.

LIPSON D.A., SCHMIDT S.K.: Seasonal Changes in an Alpine Soil Bacterial Community in the Colorado Rocky Mountains. Applied Environmental Microbiology, 70 (5): 2867-2879, 2004.

MANNINEN A.M., TARHANEN S., VUORINEN M., KAINULAINEN P.: Comparing the variation of needle and wood terpenoids in Scots pine provenances. Journal of Chemical Ecology, 28: 211-227, 2002.

MENYAILO O.V., HUNGATE B.A., ZECH W.: Tree species mediated soil chemical changes in a Siberian artificial afforestation experiment: tree species and soil chemistry. Plant and Soil, 242: 171-182, 2002.

MIKOLA P. : Experiment on the rate of decomposition of forest litter. Communicationes Instituti Forestalis Fenniae, 43: 1-50, 1954.

NIEMINEN T.M., SMOLANDER A.: Forest under-storey vegetation and plant litter decomposition under three different dominant tree species. In: Räty, M., Bärlund, I., Makkonen, K., Kähkönen, M. \& Esala, M. (eds.). Miten maamme makaa Suomen maaperä ja sen tila. IV Maaperätieteiden päivien laajennetut abstraktit. Pro Terra 29: 54-55, 2006.

PRIHA O., SMOLANDER A.: Microbial biomass and activity in soil and litter under Pinus sylvestris, Picea abies and Betula pendula at originally similar field afforestation sites. Biology and Fertility of Soils, 24: 45-51, 1997.

PRIHA O., GRAYSTON S.J., HIUKKA R., PENNANEN T., SMOLANDER A.: Microbial community structure and characteristics of the organic matter in soils under Pinus sylvestris, Picea abies and Betula pendula at two forest sites. Biology and Fertility of Soils, 33: 17-24, 2001.

ŠNAJDR J., VALÁŠKOVÁ V., MERHAUTOVÁ V., HERINKOVÁ J., CAJTHAML T., BALDRIAN P.: Spatial variability of enzyme activities and microbial biomass in the upper layers of Quercus petraea forest soil. Soil Biology and Biochemistry, 40: 2068-2075, 2008.

THALMANN A.: Zur Methodik des Bestmmung des Dehydrogenase aktivitat im Bodenmittels TTC. Landiw Forch, 21: 249-258, 1968.

THEUERL S., BUSCOT F.: Laccases: Toward disentagling their diversity and functions in relation tp soil organic matter cycling. Biology and Fertility of Soils, 46: 215-225, 2010.

TROLLDENIER G.: Plate Count Technique. In: Franz Schinner, Ellen Kandeler, Richard Ohlinger, Rosa Margesin (eds.): Methods in Soil Biology..., Germany, Springer-Verlag Berlin Heideberg: 20-26, 1996. 


\title{
MIKROBIOLOŠKA AKTIVNOST U ŠUMSKOM ZEMLJIŠTU POD SASTOJINAMA BUKVE, JELE, SMRČE I DUGLAZIJE
}

\author{
Timea HAJNAL-JAFARI, Simonida ĐURIĆ, Dragana STAMENOV, \\ Verica VASIĆ, Davorka HACKENBERGER
}

Izvod: Cilj ovog istraživanja je bio da se ispita mikrobiološka aktivnosti u zemljištu sa različitih lokaliteta pod listopadnim i četinarskim šumama u Srbiji. Jedan lokalitet na Staroj planini (SP1) je pod sastojinom bukve (Fagus sp.), dok je drugi (SP2) pod sastojinom smrče (Picea sp.) i duglazije (Pseudotsuga sp.). Lokalitet na Kopaoniku (K) je pod sastojinom bukve (Fagus sp.) i smrče (Picea sp.). Lokalitet na Tari (T) je dominantno pod sastojinama jele (Abies sp.), bukve (Fagus sp.) i smrče (Picea sp.). Ukupan broj bakterija, broj aktinomiceta, gljiva i mikroorganizama uključenih u cikluse azota (N) i ugljenika (C) su određene standardnom metodom agarnih ploča. Aktivnosti enzima dehidrogenaze i $\beta$-glukozidaze su merene spektrofotometrijski. Mikrobna aktivnost je zavisila od vrste šumskih sastojina kao i od vremena uzorkovanja zemljišta. Najveća dehidrogenaza aktivnosti, ukupan broj bakterija, broj aktinomiceta, aminoheterotrofa, amilolitskih i celulolitskih mikroorganizama su određene u zemljištu pod bukovim stablima. Najveći ukupan broj gljiva i brojnost pektinolitskih mikroorganizama su utvrđene u zemljištu pod smrčom i duglazijom. Korelaciona analiza je dokazala postojanje statistički značajne međuzavisnosti između ispitivanih parametara.

Ključne reči: mikroorganizmi, šumsko zemljište, dehidrogenaza, $\beta$-glukozidaza

Received / Primljen: 12.05.2016.

Accepted / Prihvaćen: 02.06.2016. 